Vol. 16, No, 61, October 2021, 985- 993

\title{
EVALUATION OF THE EFFECT OF ADDING BI PRODUCT FILLERS ON HMA BEHAVIOUR
}

\author{
Abdelzaher Mostafa ${ }^{1}$, Mahmoud Fouad ${ }^{1}$, Ahmed Abdelghany ${ }^{1}$ \\ ${ }^{1}$ Department of Civil Engineering, Faculty of Engineering, Helwan University
}

Received :21 April $2021 \quad$ Accepted:7 June2021

\begin{abstract}
It is obvious that the type of fillers has a significant effect on the properties of hot-mix asphalt (HMA). It is very important to understand the effect of these types of fillers on the HMA and its performance. This paper represents laboratory research into the different effects of the bi-product fillers on the properties of HMA mixture. Four types of filler and three filler contents for each were used to obtain the characteristics of HMA and to characterize the effect of filler in HMA. The effects of filler on the of HMA mixture were also studied. The properties of HMA evaluated include Marshall Test and indirect tensile (ITS). The research results showed that fillers had a great influence on the properties of HMA. With the increase of filler content, some properties of HMA improved.
\end{abstract}

KEYWORDS: Hot mix asphalt, Marshall Test, Indirect Tensile strength, Pavement cracks.

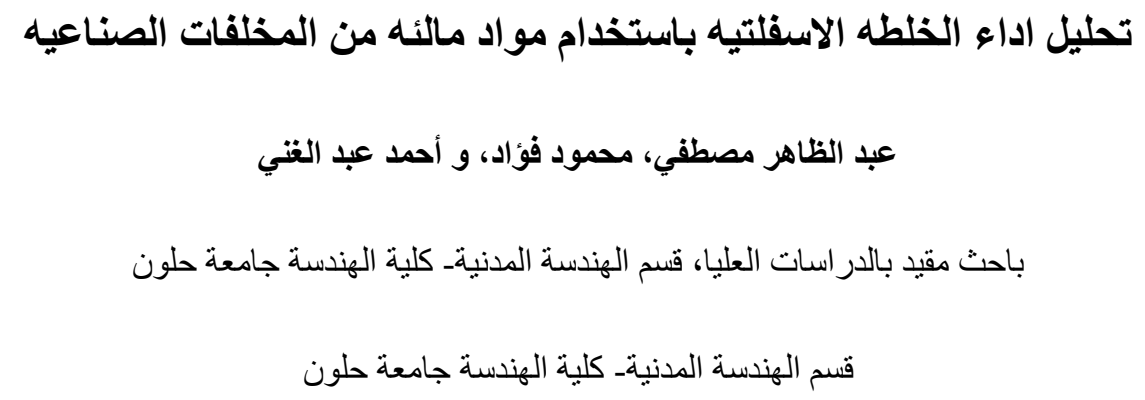




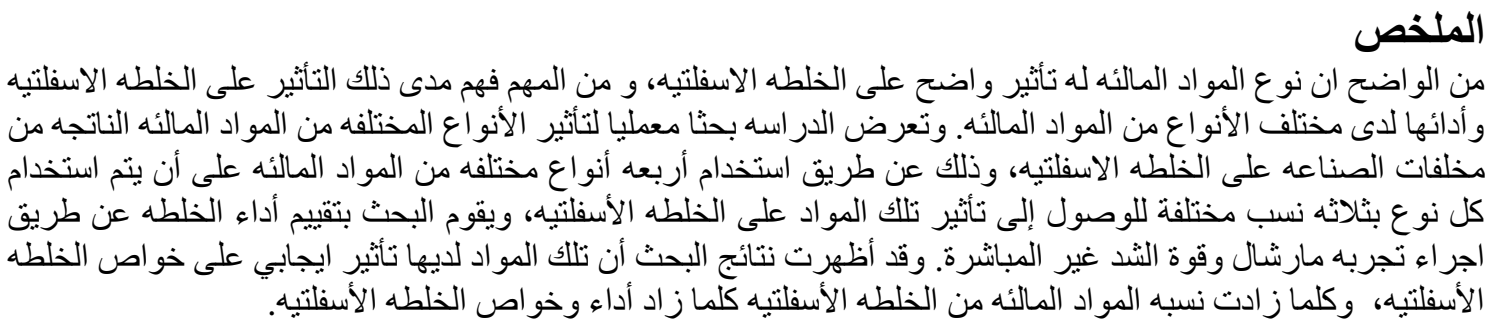

\section{INTRODUCTION}

It has been found that the filler type has a great role to play in the behavior and the performance of the HMA mixtures. The main role of the filler that it fills voids between aggregates in the mixture and modify the properties of the HMA binder, because the filler acts as an integral part of the mastic (combination of bitumen, filler, and entrapped air), The usage of the lime waste as a filler improves the stiffness and the resistance of the permanent deformation at different values of temperature [1].

The usage of the solid wastes is now taking a higher attention for the industrial countries, the continuous increasing of the by-product wastes requires a huge landfill space which could be noneconomical and harmful for the environment [2], the optimum bitumen content was found using Marshal Experiment. One of the advantages of the Marshall Mix Design method is that the performance of the mixes can be expected for local materials and environmental impact [3]. The workflow in this research provides a comparison between ten types of mixtures using four filler types. The author used red brick dust, marble dust, Hashmi brick dust and Limestone as fillers, In the study the researcher use the limestone filler in the control mix with $100 \%$ of the filler content, after getting the OPC from Marshall Test the other three fillers were added, each with three percentage with limestone filler $35 \%, 70 \%$ and $100 \%$, after the evaluation of the stability and flow of the specimens the ITS test performed.

\section{LITERATURE REVIEW}

With the significant growth of industries, diverse problems have more and more appeared, including rapid deterioration of natural resources and severe environmental contaminations. Daily accumulation of waste materials is one of the causes of these problem [4]. Recycling costs should become a considerable part of road construction because of the huge amount of money that consumed every year in recycling and solving the problems that appear in the constructed road, and on the other hand a big amount of by-products are produced every year as a result of the industry process at all levels of the industry, these waste harm the environment if it left without right usage, in this study the authors are going to investigate the effect of using a by-product powder and dust as a filler in the hot mix asphalt and find out it's effect on the performance of the hot mix asphalt mixture, The conclusion that the authors get from the results that a lime waste could be used as a good filler and, especially, And it's found that there's a significant increase in the resistance of the permanent deformation in the HMA specimens [5]. And the authority pays high attention for the usage of the by-products wastes because it could affect inflation in the cost of traditional [6]. Numerous studies have observed significant influence of filler's physical (specific gravity, particle shape, size, texture, size distribution, porosity) and chemical (mineralogy, active clay content) properties over primary pavement distresses (rutting, fatigue, low-temperature cracking, aging and moisture susceptibility [5,6]. Several researchers have reported on the formulation of new soil stabilizers by replacing the conventional additives with industrial waste products [7]. The contribution of mineral filler properties to the reduction of 
rutting in asphalt mixtures is not well understood, and contrary findings have been reported. When subjected to high temperatures and heavy traffic, roads built according to Specifications with B60/70 show high rates of permanent deformation, leading to higher repair costs. The challenge, then, is to find a balance between using better quality materials and keeping the total project cost low, particularly in developing countries [8]. In arid and hot regions, such as in North African or Middle Eastern countries, roads often deteriorate more quickly than in temperate climates. These road surfaces suffer from poor mix designs resulting in substantial deformation (e.g., rutting, shoving), especially in desert regions [9]. Fillers and modifiers are defined as fine or additives materials that work to alter the characteristics of the bitumen binders and the resulting HMA. Both in research and in industrial practice, various modifiers and fillers have been used, including polymer, fly ash, hydrated lime, fiber, clay or mineral particles, brick powder, cellulose, limestone dust, OPC, or used hard bitumen viscosity to resistance a high temperature [10].

\section{PROBLEM STATEMENT AND OBJECTIVE OF THE STUDY}

The repair cost of the roads has reached a higher limit in Egypt due to the presence of roads cracks and distresses that appears fast in the roads in a short term after construction, these cracks affect the performance of the roads and increase the rate of accidents in many spots, and repairing the roads cost the government a huge amount of money to restore the roads performance again and consume a lot of resources from the landfill.

The main objective of this study is to reduce the use of landfill resources, enhance mix performance and find out the best bi-product filler

\section{EXPERIMENTAL PROGRAM}

The Experimental program discussed in the research in five stages as follow:

5.1 materials physical and chemical properties.

5.2 Control mix design

5.3 Prepare the samples using the Four different fillers and test them using Marshall.

5.4 Select the best results from step 3 and test it with ITS.

5.5 Analysis of the results

\section{MATERIALS}

5.1. In this study the type of the used aggregate was a crushed dolomite, and the Lime was used as a filler in the control mix. The chosen aggregate properties are found to be hard, clean, and with high durability, a hot mix asphalt, prepared with a close-graded surface coarse gradation and mixed according to the specifications of the standard Egyptians code for roads (Fig.1). 


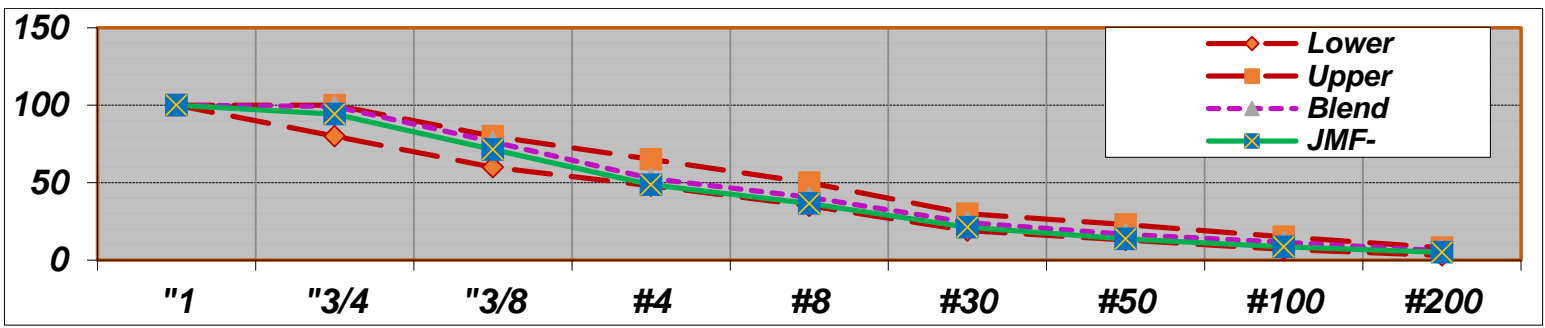

Fig.1: Aggregate gradation

Table 1: Physical characteristics of the aggregate

\begin{tabular}{|c|c|c|c|c|c|}
\hline Tested Property & Test Specification & $\mathbf{( 2 5 - 1 2 )} \mathbf{~ m m}$ & $\mathbf{( 1 2 - 9 )} \mathbf{~ m m}$ & $\mathbf{( 9 - 6 )} \mathbf{~ m m}$ & $\mathbf{( 6 - 0 )} \mathbf{~ m m}$ \\
\cline { 1 - 4 } Bulk Density & \multirow{3}{*}{ SSSD } & 2.507 & 2.515 & 2.528 & 2.611 \\
\cline { 4 - 6 } ASTM C127 & 2.533 & 2.541 & 2.548 & 2.646 \\
\cline { 3 - 6 } & & 2.714 & 2.712 & 2.719 & 2.756 \\
\hline Abrasion (LA) & \multirow{2}{*}{ ASTM C131 } & 25.5 & 26.1 & 27.1 & - \\
\hline Clay lumps & - & 0.2 & 0.1 & 0.1 & - \\
\hline Flat Elongate particles & ASTM D693 & $3.43-2.17$ & $3.21-2.37$ & $2.11-2.62$ & - \\
\hline Natural stones & - & 2.68 & 2.78 & 2.34 & - \\
\hline Water absorption & ASTM C127 & 1.81 & 1.95 & 2.1 & 1.18 \\
\hline L.L, P.L and PI & ASTM D4318 & NP & NP & NP & NP \\
\hline Sand Equivalent & ASTM C2419 & - & - & - & 56.4 \\
\hline Stripping & ASTM D1664 & Nil & Nil & Nil & - \\
\hline
\end{tabular}

5.2. Asphalt Binder: A traditional $60 / 70$ PG bitumen with a softening point equal $49.2 \mathrm{C}$, was used in the production of HMA specimens. This bitumen grade was selected as it is normally used to produce HMA mixtures. Table 2 presents the properties of the bitumen.

Table 2: The properties of the bitumen

\begin{tabular}{|c|c|c|c|c|}
\hline Test & Penetration test & Ductility test & Softening point & Flash point \\
\hline Value & $67 \mathrm{~mm}$ & 482.5 centistoke & $49.2 \mathrm{C}$ & $265 \mathrm{C}$ \\
\hline
\end{tabular}

5.3. Fillers: The fillers that used in this investigation were collected from factories wastes, Limestone was used as a control filler in the control mix, three other fillers were used (Marble dust, red brick powder, Hashmi brick powder), all the fillers passed from sieve $200 \mathrm{~mm}$, Table 3 presents the chemical of each filler from the XRF test. 
Table 3: Comparative chemical properties of XRF

\begin{tabular}{|l|l|l|l|l|l|l|l|l|l|l|l|l|l|l|}
\hline Comp. & $\mathrm{SiO}_{2}$ & $\mathrm{TiO}_{2}$ & $\mathrm{Al}_{2} \mathrm{O}_{3}$ & $\mathrm{Fe}_{2} \mathrm{O}_{3}$ & $\mathrm{MnO}$ & $\mathrm{MgO}$ & $\mathrm{CaO}$ & $\mathrm{Na} 2 \mathrm{O}$ & $\mathrm{K}_{2} \mathrm{O}$ & $\mathrm{P}_{2} \mathrm{O}_{5}$ & $\mathrm{CI}$ & $\mathrm{SO}_{3}$ & $\mathrm{LOI}$ \\
\hline \%Marble & 1.02 & 0.08 & $<0.01$ & 0.82 & $<0.01$ & 1 & 53.6 & $<0.01$ & 0.1 & 0.05 & 0.12 & $<0.01$ & 43.18 \\
\hline \%Hashmi & 8.78 & 0.14 & 0.36 & 5.94 & 0.09 & 0.27 & 46.74 & $<0.01$ & 0.18 & 0.09 & 0.39 & 0.12 & 36.7 \\
\hline$\%$ Limestone & 0.19 & 0.03 & $<0.01$ & 0.01 & $<0.01$ & $<0.01$ & 55.89 & $<0.01$ & $<0.01$ & $<0.01$ & 0.04 & $<0.01$ & 43.68 \\
\hline \%Red Brick & 49.18 & 1.96 & 13.41 & 16.21 & 0.1 & 1.84 & 6.5 & 0.26 & 1.43 & 0.04 & 0.94 & 2.33 & 5.5 \\
\hline
\end{tabular}

\section{RESULTS}

\subsection{Marshall Test Results}

The specimen's stability is defined as the maximum required load to put the specimen in a failure condition and the load application rate must be $50 \mathrm{~mm} / \mathrm{min}$. The figure below shows that the maximum stability result is $1470.643 \mathrm{~kg}$ at the percentage of $5.0 \%$ of bitumen content, and the maximum flow was at $6 \%$ bitumen content, and the bulk density is found to be maximum at the percentage of $5.4 \%$ of bitumen content and its value was $2.343 \mathrm{~g} / \mathrm{cm} 3$, it was found equal to $5.2 \%$ by weight of the total mix which is calculated as the average of bitumen content values that corresponding the maximum stability, maximum density and median of the air voids. Table 4 presents Marshall Test results.

Table 4: Control mix results

\begin{tabular}{|c|c|c|c|c|c|c|c|}
\hline Bitumen \% & $\begin{array}{c}\text { Unit } \\
\text { Wt. }\end{array}$ & $\begin{array}{c}\text { Max.sp.gr. } \\
(\text { Gmm })\end{array}$ & Air Voids \% & VMA \% & VFB \% & $\begin{array}{c}\text { Stability } \\
(\mathrm{kg})\end{array}$ & $\begin{array}{c}\text { Flow } \\
(\mathrm{mm})\end{array}$ \\
\hline 4.5 & 2.298 & 2.427 & 5.3 & 17.0 & 68.9 & 1113 & 2.7 \\
\hline 5.0 & 2.343 & 2.443 & 4.1 & 15.8 & 74.0 & 1470 & 3.1 \\
\hline 5.5 & 2.37 & 2.441 & 2.9 & 15.2 & 81.0 & 1290 & 3.3 \\
\hline 6.0 & 2.39 & 2.441 & 2.1 & 14.9 & 85.9 & 1033 & 4.1 \\
\hline
\end{tabular}




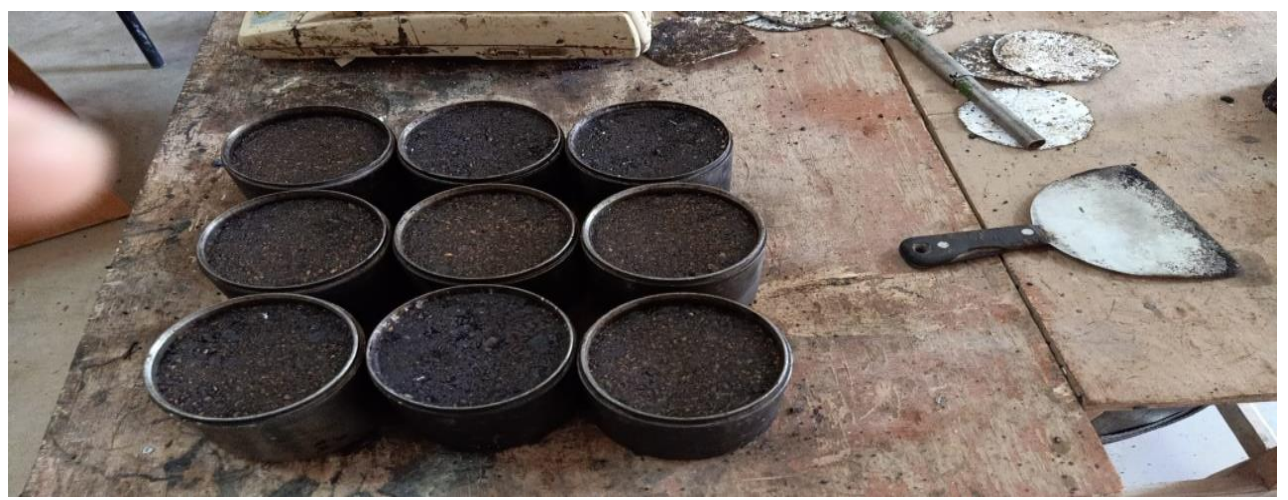

Fig.2: Asphalt specimens

\subsection{Specimen's Results}

\begin{tabular}{|l|l|l|l|l|l|l|l|l|l|l|}
\hline \multirow{2}{*}{ Filler } & $\begin{array}{l}\text { Lime } \\
100 \%\end{array}$ & $\begin{array}{l}\text { Lime } \\
0 \%\end{array}$ & $\begin{array}{l}\text { Lime } \\
35 \%\end{array}$ & $\begin{array}{l}\text { Lime } \\
65 \%\end{array}$ & $\begin{array}{l}\text { Lime } \\
0 \%\end{array}$ & $\begin{array}{l}\text { Lime } \\
35 \%\end{array}$ & $\begin{array}{l}\text { Lime } \\
65 \%\end{array}$ & $\begin{array}{c}\text { Marble } \\
\text { dust } \\
100 \%\end{array}$ & $\begin{array}{l}\text { Lime } \\
35 \%\end{array}$ & $\begin{array}{l}\text { Lime } \\
65 \%\end{array}$ \\
\cline { 2 - 12 } & & $\begin{array}{l}\text { Red } \\
\text { brick } \\
100 \%\end{array}$ & $\begin{array}{l}\text { Red } \\
\text { brick } \\
65 \%\end{array}$ & $\begin{array}{l}\text { Red } \\
\text { brick } \\
35 \%\end{array}$ & $\begin{array}{l}\text { Hash- } \\
\text { my } \\
\text { brick } \\
100 \%\end{array}$ & $\begin{array}{l}\text { Hash- } \\
\text { my } \\
\text { brick } \\
65 \%\end{array}$ & $\begin{array}{l}\text { Hash- } \\
\text { my } \\
\text { brick } \\
35 \%\end{array}$ & & $\begin{array}{l}\text { Marble } \\
\text { dust } \\
\text { Stability }\end{array}$ \\
\hline KN $)$ & 1206 & 1695 & 1524 & 1486 & 1670 & 1659 & 1633 & 1833 & 1436 & $\begin{array}{l}\text { Marble } \\
\text { dust } \\
35 \%\end{array}$ \\
\hline Flow & 3.3 & 3 & 3.5 & 3.5 & 3.2 & 3.2 & 3.3 & 3.1 & 3.5 & 3.2 \\
\hline
\end{tabular}

\subsubsection{Marshall Stability-Flow results}

It's noticed that that all values of stability with different Fillers achieve the local and international specification requirements, in red brick powder specimens it found that the stability of the HMA specimens increase by substituting the lime powder with red brick powder and it continue going up as the percent of the red brick powder increase until it reach its maximum limit when the red brick powder became $100 \%$, and the flow decrease as the red brick powder decrease until reaching its optimum percent at 100\% of red brick powder , in Hashmi brick powder specimens it found that the stability of the HMA specimens increase by substituting the lime powder with Hashmi brick powder and it continue going up as the percent of the Hashmi brick powder increase until it reach its maximum limit when the Hashmi brick powder became $100 \%$, and the flow changes were constant at the 3 percentage of Hashmi brick, in marble dust specimens it found that the stability of the HMA specimens increase by substituting the lime powder with red brick powder and it continue going up as the percent of the marble dust increase until it reach its maximum limit when the marble dust became $100 \%$, and the flow changes with a non-uniform pattern as the percentage changes. 


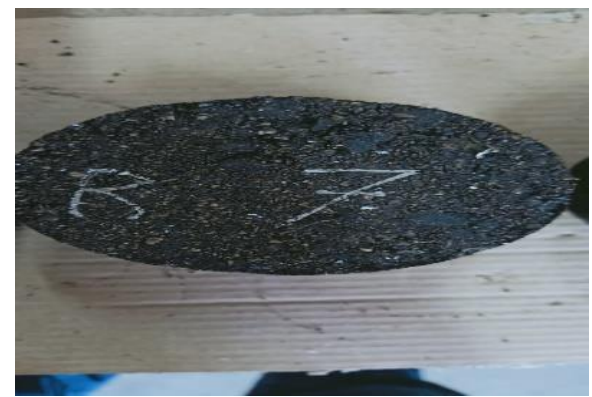

Fig.3: Asphalt sample

\subsubsection{Marshall stability-filler content relationship}

It found that the minimum stability value was at $100 \%$ lime and the stability increase as the author substitute the lime until reaching the $100 \%$ substitution, the maximum value was at $100 \%$ marble dust and the second value was with red brick and the third was with Hashmi brick powder.

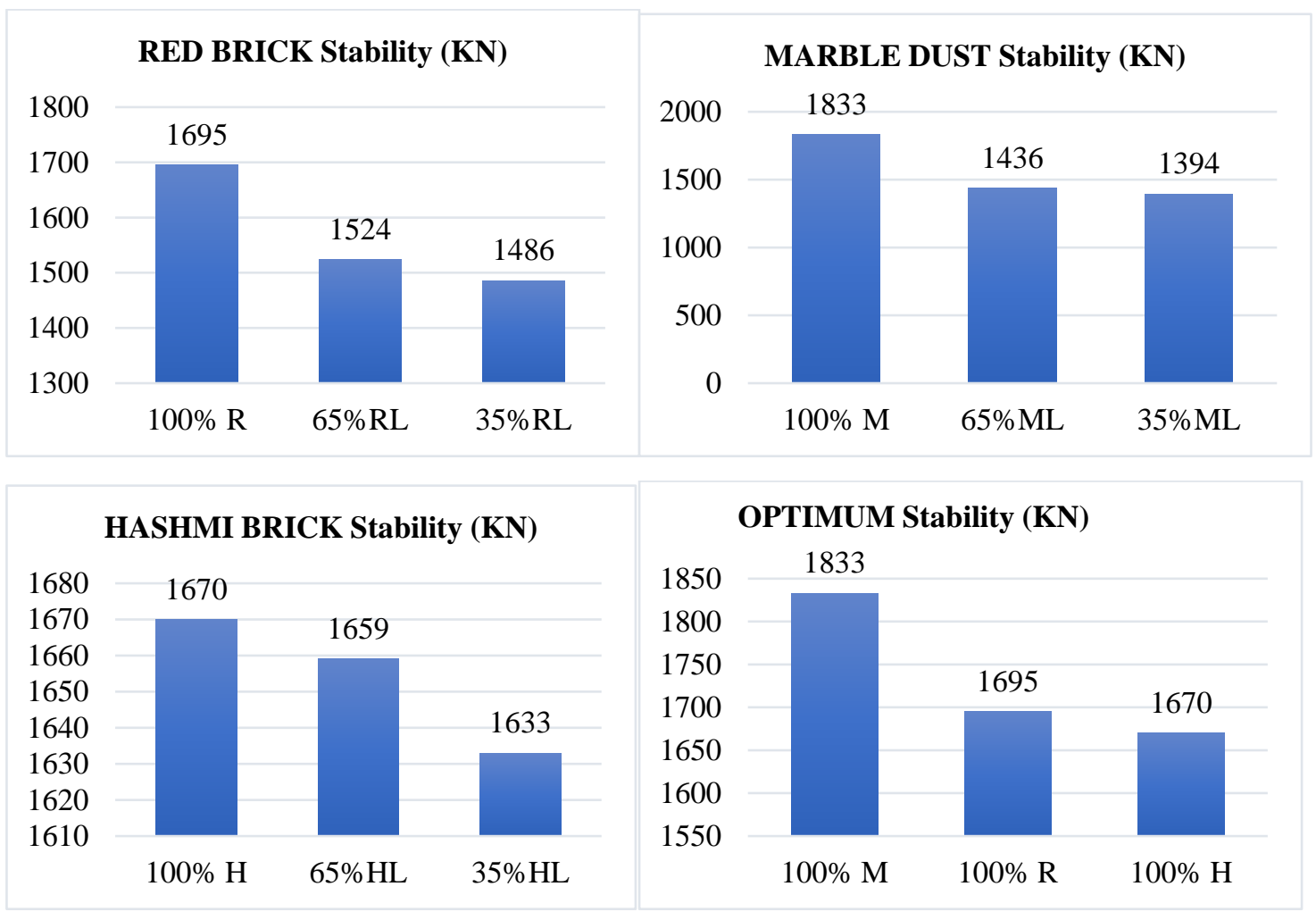

Fig.5: Marshall Stability results

\subsection{Indirect tensile strength results}

In this experiment indirect tensile strength is carried out to obtain the shear resistance of the specimens by using the best 6 types and percent of fillers, there were $100 \%$ and 67 $\%$ of all the used fillers, it's tested at dry state to obtain it, the authors found out that the best shear resistance were at the three $100 \%$ specimens, After that moisture sensitivity was going to be tested by using wet specimens in the test, the three $100 \%$ specimens get the best results in the moisture sensitivity, below the results will be discussed. 


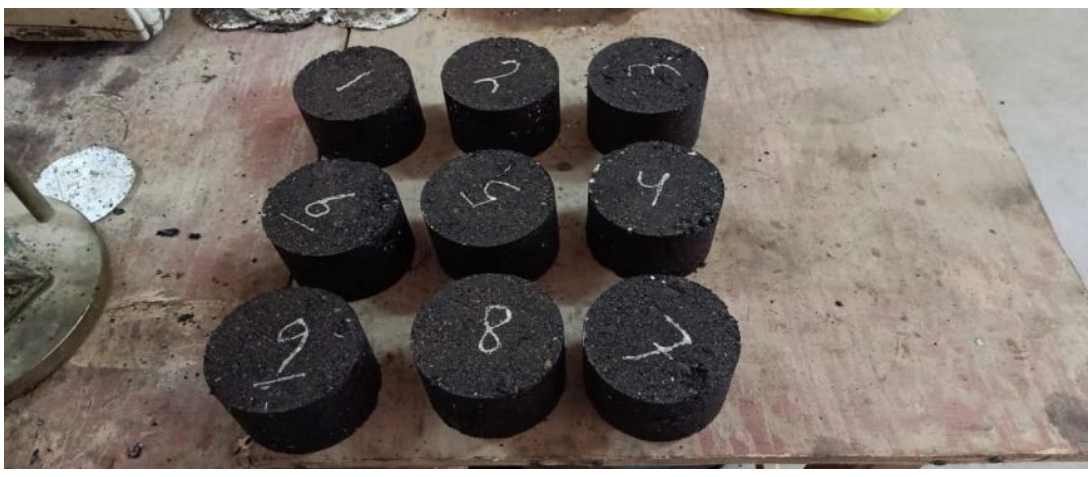

Fig.4 Indirect tensile strength Specimens

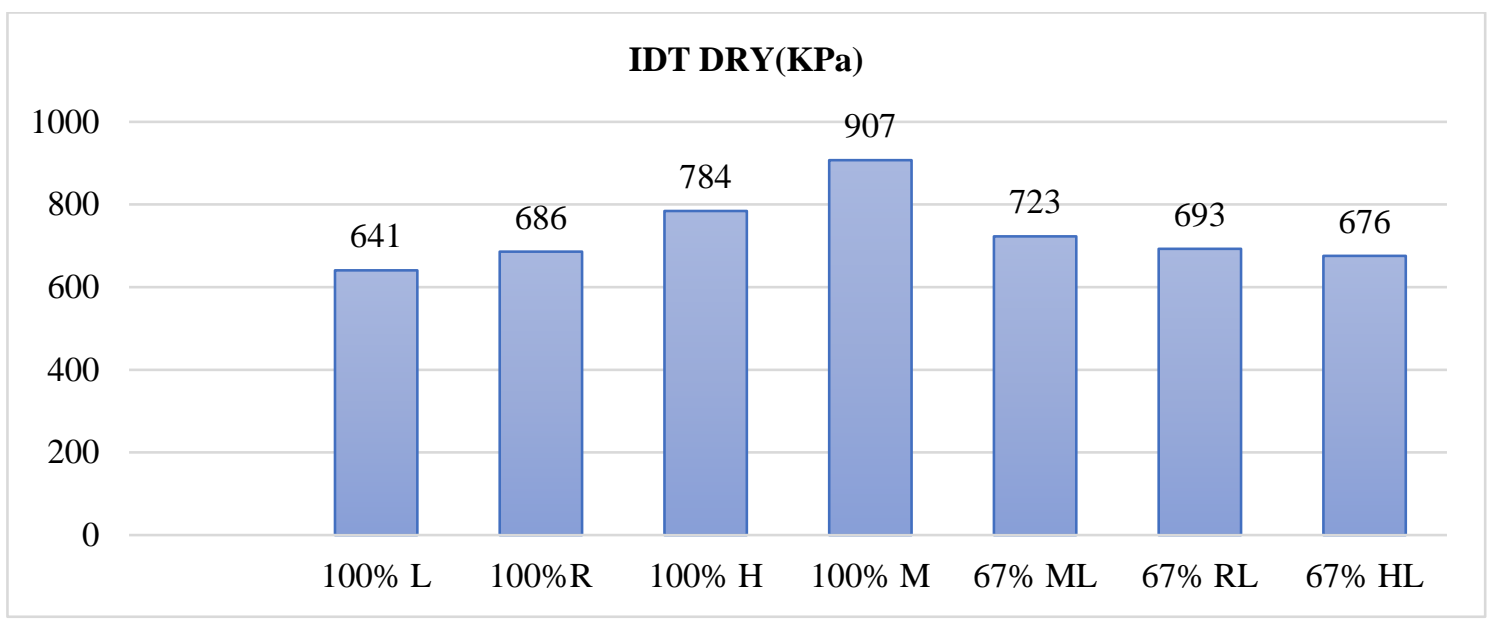

Fig.5: Indirect tensile strength results

\section{CONCLUSIONS}

1-The existence of different types of fillers (red brick powder, marble dust, Hashmi brick powder) in HMA specimens is found to be an eco-friendly bi-product material and it can be used as an effective additive.

2-The results of Marshall Stability, flow, of the specimens are within the specifications values at all percentages of the filler quantities.

3-Marshall Stability achieve the maximum results at the $100 \%$ of marble dust filler in the asphalt binder.

4-The flow always within range in all specimens of all different types of fillers.

\section{RECOMMENDATIONS}

1-Further studies are needed using different types of fillers and different percentages of filler content.

2-The research results were found very promising to be used in the construction field and to get the permission to be used by the government.

3-The authors recommended to track the application in the field and evaluate its performance by using these eco-friendly wastes. 
4- The authors recommended to investigate the effect of using another waste materials based on the most wastes spread in the investigator country.

\section{REFERENCES}

[1] Sung Do, H., Hee Mun, P., \& Suk keun, R. (2008). A study on engineering characteristics of asphalt concrete using filler with recycled waste lime. Waste Management, 28(1), 191199. doi:10.1016/j.wasman.2006.11.011

[2] Dulaimi, A., Shanbara, H. K., Jafer, H., \& Sadique, M. (2020). An evaluation of the performance of hot mix asphalt containing calcium carbide residue as a filler. Construction and Building Materials, 261, 119918. doi:10.1016/j.conbuildmat.2020.119918

[3] Sady Abd Tayh, Aqeel Raheem Jabr, 2009. The Effect of Filler Type on the Hot Mix Asphalt Behavior

[4] Abdel-Shafy, H. I., \& Mansour, M. S. M. (2018). Solid waste issue: Sources, composition, disposal, recycling, and valorization. Egyptian Journal of Petroleum. doi:10.1016/j.ejpe.2018.07.003

[5] Abed, A. H., \& Bahia, H. U. (2020). Enhancement of permanent deformation resistance of modified asphalt concrete mixtures with nano-high density polyethylene. Construction and Building Materials, 236, 117604. doi:10.1016/j.conbuildmat.2019.117604

[6] Arabani, M., Tahami, S. A., \& Taghipoor, M. (2016). Laboratory investigation of hot mix asphalt containing waste materials. Road Materials and Pavement Design, 18(3), 713729. doi:10.1080/14680629.2016.1189349

[7] James, J., \& Pandian, P. K. (2016). Industrial Wastes as Auxiliary Additives to Cement/Lime Stabilization of Soils. Advances in Civil Engineering, 2016, 1-17. doi:10.1155/2016/1267391

[8] Shanbara, H. K., Ruddock, F., \& Atherton, W. (2018). A viscoplastic model for permanent deformation prediction of reinforced cold mix asphalt. Construction and Building Materials, 186, 287-302. doi:10.1016/j.conbuildmat.2018.07.127

[9] Fathi MADWI (2020). Sand-Asphalt Mix Design with Available Materials for Hot and Arid Environments

[10] Mistry, R., \& Roy, T. K. (2016). Effect of using fly ash as alternative filler in hot mix asphalt. Perspectives in Science, 8, 307-309. doi:10.1016/j.pisc.2016.04.061 